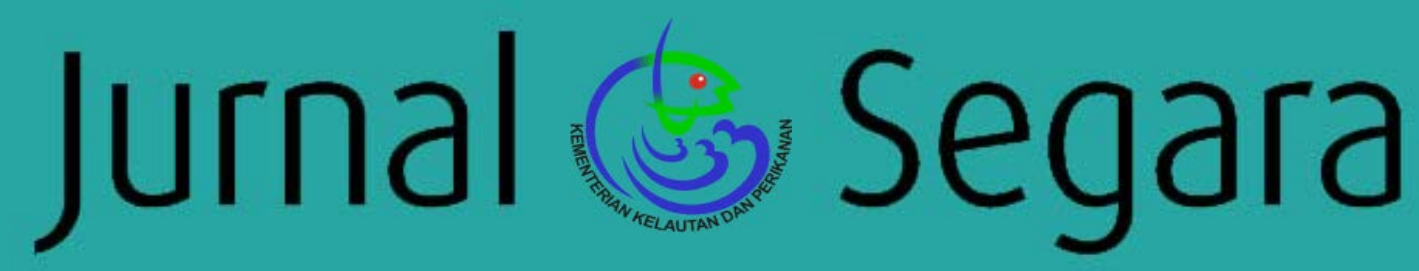

Pusat Riset Kelautan

Badan Riset dan Sumber Daya Manusia Kelautan dan Perikanan

Kementerian Kelautan dan Perikanan

ISSN 1907-0659

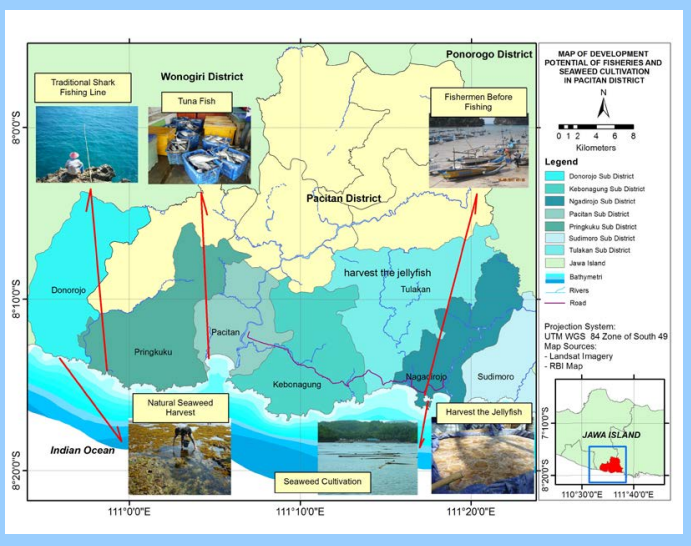

Map of Prospective Coastal Areas for Capture Fisheries and Seaweed Cultivation in Pacitan District.
THE SUITABILITY OF COASTAL AREA DEVELOPMENT BASED ON MINAWISATA CONCEPT IN PACITAN DISTRICT

Syahrial Nur Amri \& Taslim Arifin

PROGRESS ON COASTAL ECOSYSTEMS: CORALS AND MANGROVES RECOVERY 12 YEARS LATER AFTER MARCH 2005 EARTHQUAKE IN NORTH NIAS, NORTH SUMATERA

Suyarso, Bayu Prayuda \& Praditya Avianto

SEAGRASS ECOSYSTEM CARBON STOCK IN THE SMALL ISLANDS: CASE STUDY IN SPERMONDE ISLAND, SOUTH SULAWESI, INDONESIA

Agustin Rustam, Nasir Sudirman, Restu Nur Afi Ati,

Hadiwijaya Lesmana Salim \& Yusmiana Puspitaningsih Rahayu

AN OVERVIEW OF SURFACE WATER QUALITY INFLUENCED BY SUSPENDED SOLID CONTENT IN THE SAYUNG WATERS, DEMAK, INDONESIA

Ulung Jantama Wisha, Koko Ondara \& Gunardi Kusumah

THE USE OF REMOTE SENSING AND GIS TECHNOLOGY IN SUPPORTING ECOREGION MANAGEMENT

Tyas Ismi Trialfhianty, Fajrun Wahidil Muharram \& Aldian Giovanno

CHARACTERISTICS OF MARINE LITTERS IN THE WEST COAST OF BALI

Semeidi Husrin, Ulung Jantama Wisha, Rahmadi Prasetyo, Aprizon

Putra \& Adli Attamimi

\begin{tabular}{|l|l|l|l|l|l|}
\hline J. Segara & Volume 13 & Nomor 2 & Hal. 74-140 & $\begin{array}{c}\text { Jakarta } \\
\text { Agustus 2017 }\end{array}$ & $\begin{array}{l}\text { p-ISSN 1907-0659 } \\
\text { e-ISSN 2461-1166 }\end{array}$ \\
\hline
\end{tabular}




\begin{abstract}
NOLUME 13 NO.2 AGUSTUS 2017
(Periode Oktober 2016 - Oktober 2021)
Jurnal SEGARA adalah Jurnal yang diasuh oleh Pusat Riset Kelautan, Badan Riset dan Sumber Daya Manusia Kelautan dan Perikanan
- KKP, dengan tujuan menyebarluaskan informasi tentang perkembangan ilmiah bidang kelautan di Indonesia, seperti: oseanografi,
akustik dan instrumentasi, inderaja,kewilayahan sumberdaya nonhayati, energi, arkeologi bawah air dan lingkungan. Naskah yang
dimuat dalam jurnal ini terutama berasal dari hasil penelitian maupun kajian konseptual yang berkaitan dengan kelautan Indonesia, yang
dilakukan oleh para peneliti, akademisi, mahasiswa, maupun pemerhati permasalahan kelautan baik dari dalam dan luar negeri. Terbit
pertama kali tahun 2005 dengan frekuensi terbit tiga kali dalam satu tahun.
\end{abstract}
Pimpinan Redaksi/Penanggung Jawab

Kepala Pusat Riset Kelautan

Pemimpin Redaksi (Editor-in-chief)

Prof. Dr. Ngurah N. Wiadnyana (Oseanografi Biologi/Ekologi Laut) - KKP

Dewan Editor (Members of the Editorial Board)

Dr.-Ing. Widodo Setiyo Pranowo (Oseanografi Terapan) - KKP

Dr. Agustin Rustam (Oseanografi Biologi) - KKP

\begin{abstract}
Bebestari Edisi ini
Dr. rer.nat. M. Rokhis Khamarudin (Penginderaan Jauh Kelautan) - LAPAN Yudhicara, M.Sc. (Sedimentologi Kelautan) - KESDM

Noir Primadona Purba, M.Si. (Oseanografi) - UNPAD

Dr.-Ing.Widjo Kongko, M.Eng. (Teknik Pantai, Teknik Gempa/Tsunami) - BPPT

Dr. Sugiarta Wirasantosa (Geologi/Geologi Kelautan) - ITB
\end{abstract}

\author{
Redaksi Pelaksana (Executive Editor) \\ Ir. Theresia Lolita, M.Si. (Ekonomi) - KKP \\ Lydia Desmaniar, A.Md (Sistem Informasi Geografis) - KKP
}

\author{
Sekretariat Redaksi (Secretariat Staff) \\ Angriyan Kurniawan, A.Md - KKP \\ Joko Subandriyo, S.T (Teknik Elektro) - KKP
}

\author{
Design Grafis \\ Dani Saepuloh, S.Kom. (Teknik Informatika) - KKP
}

Redaksi Jurnal IImiah Segara bertempat di Kantor Pusat Balitbang Kelautan dan Perikanan

Alamat : JL. Pasir Putih I Ancol Timur Jakarta Utara 14430

Telpon : :021-6471-1583

Faksimili $\quad: 021-6471-1654$

E-mail : jurnal.segara@gmail.com

Website : : http://ejournal-balitbang.kkp.go.id/index.php/segara

Jurnal Segara Volume 13 No. 2 Agustus 2017 diterbitkan oleh Pusat Riset Kelautan Tahun Anggaran 2017 


\section{Jurnal \& Segara \\ VOLUME 13 NO.2 AGUSTUS 2017}

\section{Bebestari :}

Prof. Dr. Hasanuddin Z. Abiddin (Geodesi dan Geomatika) - ITB

Dr. Herryal Zoelkarnaen Anwar, M.Eng. (Manajemen Resiko Bencana) - LIPI

Ir. Irsan Soemantri Brodjonegoro, MSCE, Ph.D (Teknik Kelautan) - ITB Dr. Ir. Ario Damar, M.Si. (Ekologi Laut) - IPB

Dr. Makhfud Efendy (Teknologi Kelautan) - UNIVERSITAS TRUNOJOYO Prof. Dr. Safwan Hadi (Oseanografi) - ITB

Prof. Dr. Wahyoe S. Hantoro (Geologi Kelautan, Geoteknologi) - LIPI

Dr. Nani Hendiarti (Penginderaan Jauh Kelautan dan Pesisir) - BPPT

Dr. Iskhaq Iskandar, M.Sc. (Oseanografi Fisika) - UNSRI

Dr. rer.nat. Rokhis Khamarudin (Penginderaan Jauh Kelautan) - LAPAN

Dr.-Ing.Widjo Kongko, M.Eng. (Teknik Pantai, Teknik Gempa/Tsunami) - BPPT

Prof. Dr. Cecep Kusmana (Ekologi dan Silvikultur Mangrove) - IPB Dr. Hamzah Latief (Tsunami) - ITB

Dr. Ir Munasik, M.Sc (Oseanografi Biologi) - UNDIP Dr. Wahyu Widodo Pandoe (Oseanografi) - BPPT

Dr. Haryadi Permana (Geologi-Tektonik) - LIPI

Prof. Dr. Rosmawaty Peranginangin (Pasca Panen Perikanan) - KKP

Dr. rer. nat. Mutiara Rachmat Putri (Oseanografi Fisika) - ITB

Noir Primadona Purba, M.Si. (Oseanografi) - UNPAD

Dr. I. Nyoman Radiarta (Lingkungan, SIG dan Remote Sensing) - KKP

Dr. Ivonne M. Radjawane, M.Si., Ph.D. (Oseanografi Pemodelan) - ITB

Dr. Ir. Yan Rizal R., Dipl. Geol. (Geologi Lingkungan) - ITB

Lili Sarmili, M.Sc. (Geologi Kelautan) - KESDM

Ir. Tjoek Aziz Soeprapto, M.Sc (Geologi) - KESDM

Ir. Suhari, M.Sc (Pusat Sumberdaya Air Tanah dan Lingkungan) - KESDM

Prof. Dr. Ir. Bangun Mulyo Sukojo (Geodesi, Geomatika, Remote Sensing, GIS) - ITS

Dr. Agus Supangat, DEA (Oseanografi) - DNPI

Dr. Fadli Syamsudin (Oseanografi) - BPPT

Dr. Sugiarta Wirasantosa (Geologi/Geologi Kelautan) - ITB

Dr. Ir. Sam Wouthuyzen, M.Sc. (Oseanografi Perikanan) - LIPI

Yudhicara, M.Sc. (Sedimentologi Kelautan) - KESDM

Dr.rer.nat. Rina Zurida (Paleoklimat, Paleoseanografi, Paleoenvironment) - KESDM

Redaksi Jurnal IImiah Segara bertempat di Kantor Pusat Balitbang Kelautan dan Perikanan

Alamat $\quad:$ JL. Pasir Putih I Ancol Timur Jakarta Utara 14430

Telpon : :021-6471-1583

Faksimili $\quad: 021-6471-1654$

E-mail : jurnal.segara@gmail.com

Website : http://ejournal-balitbang.kkp.go.id/index.php/segara

Jurnal Segara Volume 13 No. 2 Agustus 2017 diterbitkan oleh Pusat Riset Kelautan Tahun Anggaran 2017 


\section{Jurnal \& Segara Pusat Riset Kelautan \\ Badan Riset dan Smber Daya Manusia Kelautan dan Perikanan Kementerian Kelautan dan Perikanan}

Volume 13 Nomor 2 Agustus 2017

Hal. 74 - 140

THESUITABILITYOF COASTALAREADEVELOPMENTBASEDON MINAWISATA CONCEPTI N PACITAN DISTRICT

Syahrial Nur Amri \& Taslim Arifin

PROGRESS ON COASTAL ECOSYSTEMS: CORALS AND MANGROVES RECOVERY 12 YEARS LATER AFTER MARCH 2005 EARTHQUAKE IN NORTH NIAS, NORTH SUMATERA

Suyarso, Bayu Prayuda \& Praditya Avianto

SEAGRASS ECOSYSTEM CARBON STOCK IN THE SMALL ISLANDS: CASE STUDY IN SPERMONDE ISLAND, SOUTH SULAWESI, INDONESIA

Agustin Rustam, Nasir Sudirman, Restu Nur Afi Ati,

Hadiwijaya Lesmana Salim, \& Yusmiana Puspitaningsih Rahayu

AN OVERVIEW OF SURFACE WATER QUALITY INFLUENCED BY SUSPENDED SOLID CONTENT IN THE SAYUNG WATERS, DEMAK, INDONESIA

Ulung Jantama Wisha, Koko Ondara \& Gunardi Kusumah

THE USE OF REMOTE SENSING AND GIS TECHNOLOGY IN SUPPORTING ECOREGION MANAGEMENT

Tyas Ismi Trialfhianty, Fajrun Wahidil Muharram, Aldian Giovanno

CHARACTERISTICS OF MARINE LITTERS IN THE WEST COAST OF BALI

Semeidi Husrin, Ulung Jantama Wisha, Rahmadi Prasetyo, Aprizon Putra, Adli Attamimi 


\section{INTRODUCTION OF EDITORIAL}

Jurnal Segara is scientific journal published and funded by the Marine Research Center, The Agency for Marine \& Fisheries Reseach\& Human Resources, Indonesian Ministry of Marine Affairs \& Fisheries.

Jurnal Segara Volume 13 No. 2 August 2017 is the second edition of Fiscal Year 2017. The articles contained in Jurnal Segara are the results from research and conceptual studies related to the marine and fisheries issues, conducted by researchers, academics, students, and observers from Indonesia and arround the world.

In this edition, the journal features 6 scientific articles of research on:The Suitability Of Coastal Area Development Based On Minawisata concept in Pacitan District; Progress On Coastal Ecosystems: Corals And Mangroves Recovery 12 Years Later After March 2005 Earthquake In North Nias, North Sumatera ; Seagrass Ecosystem Carbon Stock In The Small Islands: Case Study In Spermonde Island, South Sulawesi, Indonesia; An Overview Of Surface Water Quality Influenced By Suspended Solid Content In The Sayung Waters, Demak, Indonesia; The Use Of Remote Sensing And Gis Technology In Supporting Ecoregion Management; Characteristics Of Marine Litters In The West Coast Of Bali.

It is hoped that this scientific journal can contribute to the development of Indonesia marine science and technology. Finally, the Editor would like to thank the infinite participation of the researchers in this journal. 


\section{Jurnal \& Segara \\ Volume 13 Number 2 AUGUST 2017}

TABLE OF CONTENTS

INTRODUCTION OF EDITORIAL

THE SUITABILITY OF COASTAL AREA DEVELOPMENT BASED ON MINAWISATA CONCEPT IN PACITAN DISTRICT

Syahrial Nur Amri \& Taslim Arifin

PROGRESS ON COASTAL ECOSYSTEMS: CORALS AND MANGROVES RECOVERY 12 YEARS LATER AFTER MARCH 2005 EARTHQUAKE IN NORTH NIAS, NORTH SUMATERA Suyarso, Bayu Prayuda \& Praditya Avianto

SEAGRASS ECOSYSTEM CARBON STOCK IN THE SMALL ISLANDS: CASE STUDY IN SPERMONDE ISLAND, SOUTH SULAWESI, INDONESIA

Agustin Rustam, Nasir Sudirman, Restu Nur Afi Ati, Hadiwijaya Lesmana Salim \& Yusmiana Puspitaningsih Rahayu

AN OVERVIEW OF SURFACE WATER QUALITY INFLUENCED BY SUSPENDED SOLID CONTENT IN THE SAYUNG WATERS, DEMAK, INDONESIA

Ulung Jantama Wisha, Koko Ondara \& Gunardi Kusumah

THE USE OF REMOTE SENSING AND GIS TECHNOLOGY IN SUPPORTING ECOREGION MANAGEMENT

Tyas Ismi Trialfhianty, Fajrun Wahidil Muharram \& Aldian Giovanno 


\section{THE SUITABILITY OF COASTAL AREA DEVELOPMENT BASED ON MINAWISATACONCEPTIN PACITAN DISTRICT}

\section{KESESUAIAN PEMBANGUNAN KAWASAN PESISIR BERDASARKAN KONSEP MINA WISATA DI KABUPATEN PACITAN}

Syahrial Nur Amri and Taslim Arifin

\section{ABSTRAK}

Konsep minawisata merupakan implementasi dan integrasi dari upaya optimalisasi pemanfaatan sumberdaya laut dan pesisir dengan upaya menjaga kelestarian dan nilai keberlanjutannya. Penelitian ini bertujuan untuk menentukan kesesuaian pengembangan lahan kawasan pesisir Pacitan berdasarkan potensi wilayah laut dan pesisir melalui konsep minawisata. Lokasi penelitian meliputi 7 (tujuh) kecamatan pesisir di Kabupaten Pacitan Propinsi Jawa Timur, yaitu Kecamatan Donorejo, Kecamatan Pringkuku, Kecamatan Pacitan, Kecamatan Kebonagung, Kecamatan Tulakan, Kecamatan Ngadirejo, dan Kecamatan Sudimoro. Metodologi yang digunakan merupakan kombinasi analisis Sistem Informasi Geografis, interpretasi citra satelit, dan Pengolahan data lapangan. Penelitian ini dibatasi pada identifikasi potensi pemanfaatan lahan pesisir, kesesuaian pemanfaatan lahan pesisir, serta kesesuaian pengembangan lahan kawasan pesisir melalui pendekatan konsep minawisata. Hasil analisis menunjukkan bahwa terdapat tiga pemanfaatan dominan pada wilayah pesisir dan laut di Kabupaten Pacitan, diantaranya: Budidaya Laut, Perikanan Tangkap, dan Wisata Pantai. Untuk kesesuaian lahan pesisir dan laut, ketujuh kecamatan pesisir di Kabupaten Pacitan sesuai untuk kegiatan perikanan tangkap dan wisata pantai, sedangkan untuk budidaya laut, hanya dua kecamatan yang sesuai bersyarat, yaitu Kecamatan Pacitan dan Kecamatan Ngadirejo. Penerapan konsep minawisata untuk kesesuaian lahan pesisir di Kabupaten Pacitan berdasarkan hasil analisis menetapkan 7 (tujuh kawasan) minawisata yang dianggap layak untuk dikembangkan.

Kata kunci: kesesuaian lahan, pembangunan wilayah pesisir,

\section{Konsep minawisata, Pacitan
konsung}

\section{ABSTRACT}

Minawisata concept is the implementation and integration of efforts to optimize the utilization of marine and coastal resources with action to maintain the sustainability and value of sustainability. This study aimed to determine the suitability of the coastal land development in Pacitan District based on the potential of marine and coastal areas in accordance to the minawisata concept. Study area covered 7 (seven) districts along the coastline of Pacitan District, East Java Province, namely Donorejo, Pringkuku, Pacitan, Kebonagung, Tulakan, Ngadirejo, and Sudimoro District. The methodology used in this study is a combination of Geographic Information Systems analysis, satellite imagery interpretation, and field data processing. This study is limited to the identification of the potential of marine and coastal area, the suitability of land use, and the suitability of coastal area development based on the minawisata concept. The results show that there are three dominant utilizations of marine and coastal areas in Pacitan District, including: Marine Aquaculture, Capture Fisheries, and Beach Tourism. Based on the analysis on suitability of the marine and coastal area, seven districts in Pacitan are suitable for fisheries and beach tourism, while only two districts were suitable for marine aquaculture with several conditions, namely Pacitan District and Ngadirejo District. The implementation of minawisata concept for coastal area suitability based on the analysis of 7 (seven) identified districts is feasible for further development.

Keywords: land suitability, coastal area development, minawisata concept, Pacitan

\section{PROGRESS ON COASTAL ECOSYSTEMS: CORALS AND MANGROVES RECOVERY 12 YEARS LATER AFTER MARCH 2005 EARTHQUAKE IN NORTH NIAS, NORTH SUMATERA

\begin{abstract}
TPERKEMBANGAN PEMULIHAN EKOSISTEM PESISIR: KARANG DAN MANGROVE 12 TAHUN SESUDAH GEMPA MARET 2005 DI NIAS UTARA, SUMATERA UTARA
\end{abstract}

SuyaSuyarso, Bayu Prayuda \& Praditya Avianto

\section{ABSTRAK}

Duabelas tahun lalu gempa berkekuatan 9,3 Mw di Kepulauan Andaman pada 26 Desember 2004 yang disertai dengan kejadian tsunami di wilayah Aceh menyebabkan kerugian yang luar biasa, belum pernah terjadi sebelumnya untuk kehidupan manusia di wilayah pesisir Indonesia dan negara-negara tetangga. Beberapa bulan kemudian, yakni pada tanggal 28 Maret 2005, gempa berkekuatan 8,7 Mw telah terjadi di Nias, ratusan hektar ekosistem terumbu karang terangkat menjadi daratan, banyak karang mati karena kekeringan dan runtuh karena getaran gempa. Demikian pula sebagian mangrove berpindah menjauh dari garis pantai karena proses pengangkatan daratan. Tujuan penelitian ini untuk mengetahui perkembangan ekosistem pesisir khususnya karang yang telah rusak akibat gempa dan mangrove yang telah mengalami perubahan lingkungan. Metode yang dipergunakan dalam penelitian adalah menganalisis data menggunakan teknik

\section{ABSTRACT}

Twelve years ago 9.3 Mw earthquake in the Andaman Islands, on December 26, 2004 accompanied by the tsunami in Aceh led to extraordinary losses, unprecedented for human life in coastal areas of Indonesia and neighboring countries. A few months later, on March 28,2005 an earthquake $8.7 \mathrm{Mw}$ has occured around Nias, hundreds of hectares of coral reef ecosystems lifted into the terrestrial, many corals died of drought and collapse due to earthquake vibration. Similarly, most of the mangrove moved away from the coastline due to land lifting. The purpose of this study is to determine the development of coastal ecosystems, especially coral reefs have been damaged by the earthquake and mangrove due to changes in the environment. The method used in this study is remote sensing technique through the data acquired from landsat imageries, measurements of coastal profile, coral reef health monitoring data collected in each year at six permanent stations. The field surveys were conducted in August 
penginderaan jauh berdasar citra landsat, melakukan pengukuran profil pantai, pengumpulan data perkembangan kesehatan terumbu karang yang diperoleh setiap tahun pada 6 stasiun tetap sedangkan penelitian lapangan telah dilakukan pada Augustus 2005, Desember 2014 and Desember 2015. Dua kegiatan penelitian tersebut terakhir merupakan kerjasama antara Dinas Kelautan Kabupaten Nias Utara dengan Pusat Penelitian Oseanografi LIPI. Hasil penelitian menunjukkan bahwa periode 2007-2010 pemulihan tutupan karang hidup dengan kisaran 2,23\%-48\%. Namun sebaliknya, pada tahun 2014 secara ironis menunjukkan penurunan tutupan karang hidup di hampir semua stasiun. Gempa yang terjadi dua kali pada waktu yang hampir bersamaan dan berkekuatan 8,2 Mw dan 8,6 Mw pada 11 April 2012 di 400 km barat daya Aceh diduga berperan dalam meruntuhkan karang yang sedang berkembang. Demikian pula keberadaan mangrove yang telah berpindah menjauhi garis pantai akibat pengangkatan daratan pada 2005, khususnya jenis Rhyzophora perlahan mati kekeringan sedangkan Aegiceras Dolichandrone, Xylocarpus dan Ceriop dapat bertahan.
2005, December 2014 and December 2015, the last two activities were under research collaboration between the Marine Agency of North Nias Regency and Research Center for Oceanography LIPI. The results showed in the period 2007-2010 live coral coverage is likely to increase in the range between $2.23 \%$ to $48 \%$. Instead since 2014 showed a significant decrease in almost all stations. Twice earthquakes with 33the magnitude $8.2 \mathrm{Mw}$ and $8.6 \mathrm{Mw}$ occurred almost simultaneously on April 11, 2012 at $400 \mathrm{~km}$ southwest of Aceh is thought to play a role in tear down the developing corals. Similarly, the existence of mangrove that has moved away from the coastline due to the land lifting in 2005 , species of Rhyzophora desiccated and died slowly but other species such as Aegiceras, Dolichandrone, Xylocarpus and Cheriops appear stayed on the dry land condition and seemed to be growing normally.

Keywords: coastal ecosystems, recovery 12 years later, March 2005 earthquake, North Nias, North Sumatera.

Kata kunci: Gempa, perusakan, pemulihan, ekosistem pesisir, Nias Utara, Sumatera Utara.

\title{
SEAGRASS ECOSYSTEM CARBON STOCK IN THE SMALL ISLANDS: CASE STUDY IN SPERMONDE ISLAND, SOUTH SULAWESI, INDONESIA
}

\section{KARBON STOK EKOSISTEM LAMUN DI PULAU-PULAU KECIL: STUDI KASUS KEPULAUAN SPERMONDE, SULAWESI SELATAN, INDONESIA}

\author{
Agustin Rustam, Nasir Sudirman, Restu Nur Afi Ati, \\ Hadiwijaya Lesmana Salim, \& Yusmiana Puspitaningsih Rahayu
}

\section{ABSTRAK}

Pulau-pulau kecil umumnya kaya dengan ekosistem terumbu karang dan ekosistem lamun dan tanaman pantai. Ekosistem lamun merupakan salah satu ekosistem pesisir karbon biru, yang mampu menyimpan memanfaatkan $\mathrm{CO}_{2}$ dan menyimpan dalam bentuk karbon organik dalam biomassa dan sedimen.. Tujuan penelitian ini mendapatkan karbon stok ekosistem lamun dan peranannya dalam perubahan iklim. Metode penelitian yang dilakukan metode surve dengan pengambilan sampel secara purposive sampling yang mewakili seluruh lokasi penelitian dan dianalisis besarnya karbon yang terkandung dalam biomassa dan sedimen. Hasil penelitian yang didapat adalah dari delapan spesies lamun yang ditemukan nilai karbon tertinggi pada jenis Enhalus acoroides di pulau Kapoposang 1,64 $\mathrm{MgCha}^{-1}$. Nilai rata-rata biomasa total stok karbon lamun terbesar di pulau Bauluang 1.89 0,92 MgCha $^{-1}$ dengan komposisi terbesar di bagian below ground sebesar $77 \%$ dari karbon total biomasa. Karbon stok total dalam sedimen pada penelitian ini

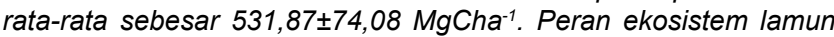
di perairan Kepulauan Spermonde dalam perubahan iklim baik di biomassa dan sedimen sebesar 533,25 $\mathrm{MgCha}^{-1}$ setara dengan pemanfaatan $\mathrm{CO}_{2}$ sebesar 1955,26 $\mathrm{MgCO}_{2 e}$ ha $^{-1}$.

Kata kunci: Lamun, Kepulauan Spermonde, karbon biru, mitigasi

\section{ABSTRACT}

Small islands are particularly rich with coral reefs, seagrass ecosystems and coastal plants. Seagrass meadow is one of the blue carbon ecosystems, which is able to store $\mathrm{CO}_{2}$ in the form of organic carbon inside its biomass and sediment. The objectives of this study were to determine the carbon stock of seagrass in Spermonde Island and to review its essential role in climate change mitigation strategies. The purposive sampling method was undertaken to ensure a spatially representative research site and analyzed the amount of carbon contained in biomass and sediment. The results show that there were eight species of seagrass across the islands with the highest carbon stock derived from Enhalus acoroides species at Kapoposang island constituting $1.64 \mathrm{MgCha}^{-1}$. The average carbon stock of the total biomass (above-and below ground) in the largest island (Bauluang island) was $1.89 \pm 0.92 \mathrm{MgC} \mathrm{ha}^{-1}$ with $77 \%$ of carbon was derived from below ground component. The average of total sediment carbon stock in this study was $531.87 \pm 74.08$ $\mathrm{MgC} \mathrm{ha-1}$. The role of seagrass ecosystem in Spermonde islands in climate change mitigation was equivalent to the sequesteration of $\mathrm{CO}_{2}$ for $1955.26 \mathrm{MgCO}_{2 \mathrm{e}} \mathrm{ha}^{-1}$.

Keywords: Seagrass, Spermonde Islands, blue carbon, mitigation. 


\title{
AN OVERVIEW OF SURFACE WATER QUALITY INFLUENCED \\ BY SUSPENDED SOLID CONTENT IN THE SAYUNG WATERS, DEMAK, INDONESIA
}

\author{
PENINJAUAN KUALITAS AIR PERMUKAAN YANG DIPENGARUHI \\ OLEH MUATAN PADATAN TERSUSPENSI DI PERAIRAN SAYUNG, DEMAK, INDONESIA
}

Ulung Jantama Wisha, Koko Ondara \& Gunardi Kusumah

ABSTRAK

Abrasi yang terjadi di pesisir Sayung dipicu oleh pengaruh besar dari perubahan iklim termasuk kenaikan muka air laut dan penurunan muka tanah. Degradasi yang terjadi pada akhirnya mempengaruhi perubahan kondisi lingkungan yang ada. Tujuan dari penelitian ini adalah untuk mengetahui kondisi perairan terkini dilihat dari aspek biolgi dan kimia oseanografi akibat peningkatan konsentrasi padatan tersuspensi di perairan Sayung. Teknik yang digunakan adalah purposive sampling. Data-data yang diperoleh kemudian diolah secara statistik dan spasial. Nilai padatan tersuspensi berkisar antara 23,1-199,6 mg/L. Distribusi padatan tersuspensi disimulasikan hanya pada kondisi surut menuju pasang dengan kecepatan arus berkisar antara 0-0,41 m/s. kami menemukan nilai oksigen terlarut cukup tinggi yang mengindikasikan wilayah subur dengan tingkat polusi rendah dan kecenderungan blooming. Pada stasiun yang didominasi oleh padatan tersuspensi dan kekeruhan yang tinggi, ditemukan bahwa konsentrasi klorofil-a menurun. Kondisi material padatan tersuspensi yang tinggi secara langsung meningkatkan kekeruhan perairan dan secara tidak langsung menurunkan aktivitas fotosintesis dan menghambat siklus oksigen. Hal tersebut berdampak terhadap penurunan produktivitas primer di perairan Sayung.

Kata kunci: Hidrodinamika, Perairan Sayung, padatan tersuspensi, Kualitas air

\section{ABSTRACT}

Abrasion which is occurred in the Sayung coast is triggered by a big role of climate change as well as the sea level rise and land subsidence. Resulting degradation ultimately affects changes in existing environmental conditions. This study aims to determine the existing water based on biological and chemical content which is affected by increasing suspended solid content in the Sayung waters. Purposive sampling technique was applied. Data were analyzed both statistically and spatially. Suspended solid value ranged between 23,1-199,6 mg/L. Distribution of suspended solid was only simulated during low tide towards high tide phase with current speed of 0-0.41 $\mathrm{m} / \mathrm{s}$. We found that dissolved oxygen value was quite high in several observation stations which indicates the fertile area with low pollution and blooming tendency. In the station where suspended solid and turbidity were high, the chlorophyll-a contents were decreased. The high concentration of suspended solid directly triggers the turbidity enhancement and declines the photosynthesis activity, which is related with marine pollution. Resulting in the primary productivity reduction in the Sayung waters.

Keywords: Hydrodynamics, Sayung waters, Suspended solid content, Water quality

\section{THE USE OF REMOTE SENSING AND GIS TECHNOLOGY IN SUPPORTING ECOREGION MANAGEMENT}

\section{PENGGUNAAN PENGINDRAAN JAUH DAN TEKNOLOGI GIS UNTUK MENDUKUNG MANAJEMEN EKOREGION}

Tyas Ismi Trialfhianty, Fajrun Wahidil Muharram \& Aldian Giovanno

ABSTRAK

Kawasan pesisir menyediakan banyak manfaat untuk kehidupan manusia. Di banyak pulau-pulau terpencil, ekosistem pesisir menyediakan makanan dan bahan bangunan yang diekstraksi dari vegetasi pesisir seperti mangrove. Oleh karenanya, sangat penting untuk memastikan keberlanjutan ekosistem pesisir. Penelitian ini menghasilkan data dan peta untuk mendukung manajemen ekoregion pesisir dengan mengunakan gambar satelit pengindraan jauh, teknologi GIS, dan observasi lapangan. Data pengindraan jauh dan GIS diambil dari Google Earth dan dianalisis menggunakan ArcGIS. Kombinasi antara pekerjaan laboratorium dan lapangan digunakan untuk menyediakan gambaran menyeluruh daerah pesisir di Pulau Jefman, Raja Ampat, Papua Barat. Hasil penelitian ini menunjukan berbagai macam habitat dan vegetasi di dasar pesisir Pulau Jefman. Hasil tersebut juga menunjukan kelimpahan dan keanekaragaman terumbu karang dan ikan karang sebagai komunitas utama yang hidup di pulau tersebut, sebanyak $22 \%$ tutupan terumbu karang yang terdiri atas 12 famili karang dan indeks keberagaman ikan karang sebesar 1.20 - 2.52 dengan nilai kelimpahan sebesar 231 ind/50 m2. Lebih lanjut, komunitas lain seperti lamun, rumput laut, dan mangrove juga dijelaskan, sebagai komunitas yang juga memegang peranan penting untuk mendukung keseluruhan sistem ekologi pesisir. Berdasarkan hasil data analisis peta, kami menemukan satu area yang harus segera dilindungi. Pengindraan jauh dan teknologi GIS sangat bermanfaat untuk membantu para pengelola dalam merancang strategi pengelolaan pesisir di masa mendatang.

Kata kunci: area pesisir, manajemen ekoregion, GIS, habitat, Pulau Jefman dan pengindraan jauh.

\section{ABSTRACT}

Coastal areas provide great benefits for human lives. In many isolated islands, coastal ecosystem provides food and building materials extracted from coastal vegetation e.g. mangroves. Therefore, it is essential to ensure the sustainability of the coastal ecosystem. This study provides data and a map in supporting the coastal ecoregion management, by using remote sensing satellite imagery, GIS technology, and field observation. Remote sensing and GIS data were obtained from Google Earth and analysed by ArcGIS. The combination of both laboratory and field work were carried out to provide a broad picture of the coastal area in Jefman Island, Raja Ampat, West Papua. The results of this study showed various habitats and vegetation in the Jefman seabed area. It also demonstrates that the abundance and diversity of coral reef and reef fishes are the major community constructing the island, amounting $22 \%$ coral cover with 12 families and diversity index $1.20-2.52$ for reef fish with fish density about 231 ind $/ 50 \mathrm{~m}^{2}$. Furthermore, other communities such as seagrass, seaweed, and mangrove are also briefly explained, as they also play a greater role in supporting the whole coastal ecological system. Based on map data analysis, we found a particular area that urgently needs to be protected. Remote sensing and GIS technology were found useful to help the manager to design coastal management strategies in the future.

Keywords: coastal area, ecoregion management, GIS, habitat, Jefman Island and remote sensing. 


\title{
CHARACTERISTICS OF MARINE LITTERS IN THE WEST COAST OF BALI
}

\section{KARAKTERISTIK KELAUTAN DI PANTAI BARAT BALI}

\author{
Semeidi Husrin, Ulung Jantama Wisha, Rahmadi Prasetyo, Aprizon Putra \& Adli Attamim
}

ABSTRAK

Pantai Kuta - Bali sebagai salah satu tujuan utama pariwisata mengalami bencana pencemaran sampah setiap tahun. Berbagai upaya sudah dilakukan pemerintah setempat untuk menangani bencana sampah tersebut mulai dari upaya penyadaran akan kebersihan hingga upaya aktif pembersihan sampah secara manual di kawasan pesisir. Penelitian ini bertujuan untuk memahami fenomena pencemaran sampah di kawasan Kuta dan sekitarnya terutama dari aspek-aspek fisik seperti pergerakan dan distrbusinya di sepanjang pesisir dan di kolom air pada dua musim yang berbeda (Musim Barat dan Musim Transisi) untuk jenis kedua sampah plastik dan kayu. Model hidrodinamika digunakan untuk memahami pergerakan sampah dari perairan sekitar Pulau Jawa hingga Pantai Kuta dengan mempertimbangkan beberapa sumber sampah di muara-muara sungai di sepanjang pesisir selatan Bali untuk dua musim yang berbeda. Survey lapangan juga dilakukan tidak hanya mendata sampah yang ada di permukaan tetapi juga sampah yang ada di dasar perairan. Hasil dari simulasi hidrodinamika memperlihatkan bahwa kecepatan arus pada musim barat berkisar antara 0,05$1,75 \mathrm{~m} / \mathrm{s}$ yang terlihat jelas mampu mengangkut material apung tidak hanya dari Selat Bali tetapi juga dari sumber-sumber lainnya di sepanjang pantai selatan Bali. Sebaliknya, di Musim Transisi sampah terlihat tidak bergerak ke pesisir Kuta. Demikian juga dengan sampah yang berada di dasar peperairan. Konsentrasi sampah mendekati kawasan pesisir jauh lebih besar dibanding daerah lepas pantai. Hasil survei terhadap penduduk lokal memperlihatkan bahwa aspek terpenting dalam penanganan sampah di Kuta adalah kesadaran masyarakat dalam menjaga kebersihan.

Kata kunci: sampah, pencemaran, hidrodinamika, Kuta, Bali.

\section{ABSTRACT}

Kuta beach in Bali is a world-famous tourist destination has been suffering from marine litters (or debris) disaster almost every year. Mitigation efforts have been carried out by the local government started from educating the people as well as continuing mass cleaning campaigns for the stranded litters in the beach. The research has an objective to understand the physical processes of marine debris characteristics in Kuta such as its propagation and distribution along the coastline and in the water columns during the two different seasons (West Monsoon and Transitional seasons). A hydrodynamic model was developed to investigate the transport of marine litters from their sources by considering the tide-driven surface currents and wind. Field surveys were also conducted to assess marine litter's characteristics in the surface and in the sea beds for both plastic and wood types of litters. Hydrodynamic simulation shows that the surface current ranging from $0.05-1.75 \mathrm{~m} / \mathrm{s}$ is capable of transporting marine surface debris from Bali Straits and other sources in the South of Bali to Kuta during West Monsoon season. The collected litters during the West Monsoon season were four times larger in quantity. The concentration of litters in the seabed and in the water column is larger near to the coastline than further offshore. In the meantime, during Transitional season, Kuta was completely free from marine litters. Results from surveys also showed that the most effective measures for marine litters in Kuta is self-awareness of the people to keep the environment clean.

Keywords: marine litters, pollution, hydrodynamics, Kuta, Bali. 